\title{
Occurrence of infection by Toxoplasma gondii in slaughtered swine in the northwestern region of Paraná, Brazil
}

\section{Ocorrência da infecção por Toxoplasma gondii em suínos abatidos na região noroeste do Paraná, Brasil}

\author{
Hannah Lia Ettiene Peruch Lemos dos Santos ${ }^{1}$; Roberta Lemos Freire ${ }^{2}$; \\ Luiz Sérgio Merlini ${ }^{*}$; Paulo Henrique Sposito ${ }^{4}$; Jonathan Soares Lima ${ }^{4}$; \\ Italmar Teodorico Navarro ${ }^{2}$
}

\begin{abstract}
This study aimed to determine the prevalence of Toxoplasma gondii in swine slaughtered in Iporã, Northwest Paraná state. Blood samples were obtained from 500 finishing swine. All animals were raised under intensive farming; the blood samples were analyzed using the immunofluorescence antibody test (IFAT). Animals with titers of $\geq 64$ were considered positive for $T$. gondii infection. Of the tested samples, $63(12.6 \%)$ were positive by IFAT; $58(92.06 \%)$ of these showed titers of $64(4.7 \%)$, with titers 256 and two (3.1\%) titers of 1024 . These pigs might be considered a source of $T$. gondii infection for humans.
\end{abstract}

Key words: Toxoplasmosis, pig, prevalence, IFI

\section{Resumo}

O trabalho teve como objetivo determinar a soroprevalência de Toxoplasma gondii em suínos de um matadouro frigorífico em Iporã, região noroeste do Paraná. Amostras sanguíneas de 500 suínos de terminação, provenientes de granjas de criação intensiva, foram processadas utilizando-se a Reação de Imunofluorescência Indireta (RIFI). Os animais com título $\geq 64$ foram considerados positivos. Dentre as amostras testadas, $63(12,6 \%)$ foram positivas pela IFI. Sendo $58(92,06 \%)$ com título $64(4,7 \%)$ com título 256 e duas $(3,1 \%)$ com titulação 1024 . Estes suínos podem ser considerados uma fonte de infecção ao homem.

Palavras-chave: Toxoplasmose, suínos, soroprevalência, IFI.

\footnotetext{
${ }^{1}$ Residente curso de Medicina Veterinária, Universidade Estadual de Londrina, UEL, Londrina, PR, Brasil. E-mail: hannahlep@ hotmail.com

2 Profs. Drs., Pesquisadores, Dept ${ }^{\circ}$ de Medicina Veterinária Preventiva, UEL, Londrina, PR, Brasil. E-mail: rlfreire@uel.br; italmar@uel.br

${ }^{3}$ Pesquisador, Universidade Paranaense, UNIPAR, Umuarama, PR, Brasil. E-mail: merlini@unipar.br

${ }^{4}$ Discentes do curso de Medicina Veterinária, Universidade Paranaense, UNIPAR, Umuarama, PR, Brasil. E-mail: paulohsposito@ gmail.com; jonathansoaresdelima@gmail.com

* Author for correspondence
} 


\section{Introduction}

Toxoplasma gondii is an obligate intracellular parasite of the genus Apicomplexa; it is known to affect a wide range of hosts, including humans. Estimates indicate that this coccidian parasite infects one-third of the warm-blooded animal population and is therefore an important pathogen of medical and veterinary interest (KIM; WEISS, 2008).

Species of the Felidae family are the definitive hosts of this parasite; they have a life cycle with sexual and asexual stages (FRENKEL, 1973) and play a key role in disease transmission in humans and other animals, which contribute to the maintenance of the agent in the environment (DUBEY et al., 2005).

This infection is transmitted to humans in three main ways: the ingestion of tissue cysts in raw or undercooked meat, the ingestion of oocyst spores, and the transplacental route (FRENKEL, 1990). The consumption of raw or undercooked pork infected with $T$. gondii involves a risk of toxoplasmic infection in humans (DUBEY, 2009). The spread of infection in humans is promoted by the high prevalence of infection in domestic and wild animal species, mainly in sheep and pigs (NAVARRO et al., 1992).

Pork meat is the most consumed worldwide and can therefore serve as a source of disease transmission. Brazil is one of the largest pork meat exporters, and the state of Paraná emerges as the third largest producer of pork meat in the southern region, with a breeding stock representing 15\% of the national herd. The city of Toledo, in which a higher number of seropositive animals were found, has the largest herd of pigs in the state, with 544,200 animals. Marechal Cândido Rondon is second on this list, with 324,000 animals. The micro-region of Toledo has the third largest herd in Brazil (BRASIL, 2012).

The prevalence of $T$. gondii infection in pigs throughout the world and in Brazil varies greatly according to location, livestock category, presence of technological improvements in farms, presence of cats on farms, measures of rodent control on properties, water management strategies used, food, etc. (HILL et al., 2010; DUBEY, 2009).

In recent years, there has been an increase in technology-dependent production of pork; this might have contributed to a decrease in the seroprevalence of infection in these animals.

This study aimed to determine the prevalence of anti- $T$. gondii antibodies in pigs slaughtered in the northwestern region of Paraná, Brazil.

\section{Materials and Methods}

\section{Study area and sampling}

Samples were collected from 100 batches of finishing pigs, five sample from each batch, totaling 500 samples. All animals were raised under intensive farming and were from towns in the northern and northwestern region of Paraná, Brazil, in the following municipalities: Toledo, Nova Santa Rosa, Maripá, Altônia, Marechal Cândido Rondon, Esperança Nova, Iporã, Ouro Verde do Oeste, São Pedro do Iguaçu, and São Jorge do Patrocínio. The slaughterer in which the samples were collected is located in the northwestern region of Paraná and regulated by the Federal Inspection Service (FIS).

\section{Collection}

Blood samples were collected from February to October 2013 during slaughter in glass tubes, identified, and kept under refrigeration until they were brought to the laboratory. They were centrifuged, and the serum was separated and frozen for later use and maintained at a temperature of $-20^{\circ} \mathrm{C}$ until indirect immunofluorescence (IFI) was conducted. 


\section{Antigen preparation for immunofluorescence}

The antigen used for sensitization of immunofluorescence slides was obtained from T. gondii RH strain and maintained in mice at the Zoonoses and Public Health Laboratory at the State University of Londrina.

\section{Immunofluorescence technique}

Sera were tested using the indirect immunofluorescence test (IFI) for the detection of IgG class anti-T. gondii antibodies, according to the technique described by Camargo (1973), by using a specific anti-IgG serum for pig species. These antibodies were produced by inoculating rabbits and were conjugated to fluorescein isothiocyanate
(Sigma-Chemical). In all the reactions, previously reported positive and negative standard sera were included. The analysis was conducted using the NIKON immunofluorescence microscope. Animals with titers $\geq 64$ were considered positive. Serum samples with reagents diluted 1:64 and 1:256 were subjected to four-fold serial dilution to obtain the highest positive dilution in IFI. The serum titer was the reciprocal of the highest dilution that was positive.

\section{Results and Discussion}

Of the total 500 samples tested, $12.6 \%$ were positive, and $92.06 \%, 4.7 \%$, and $3.1 \%$ had titers of 64,256 , and 1,024, respectively. The cities in which positive animals were found are listed in Figure 1.

Figure 1. Micro-regions in west and northwestern Paraná (detail). The highlighted cities represent Toledo: 22 seropositive (red); Nova Santa Rosa: 9 seropositive (purple); Maripá: 7 seropositive (blue); Altônia: 6 seropositive (orange); Marechal Cândido Rondon: 6 seropositive (yellow); Esperança Nova: 4 seropositive (pink); Iporã: 3 seropositive (green); Ouro Verde do Oeste: 3 seropositive (gray); São Pedro do Iguaçu: 2 seropositive (brown); São Jorge do Patrocínio: 1 seropositive (beige).

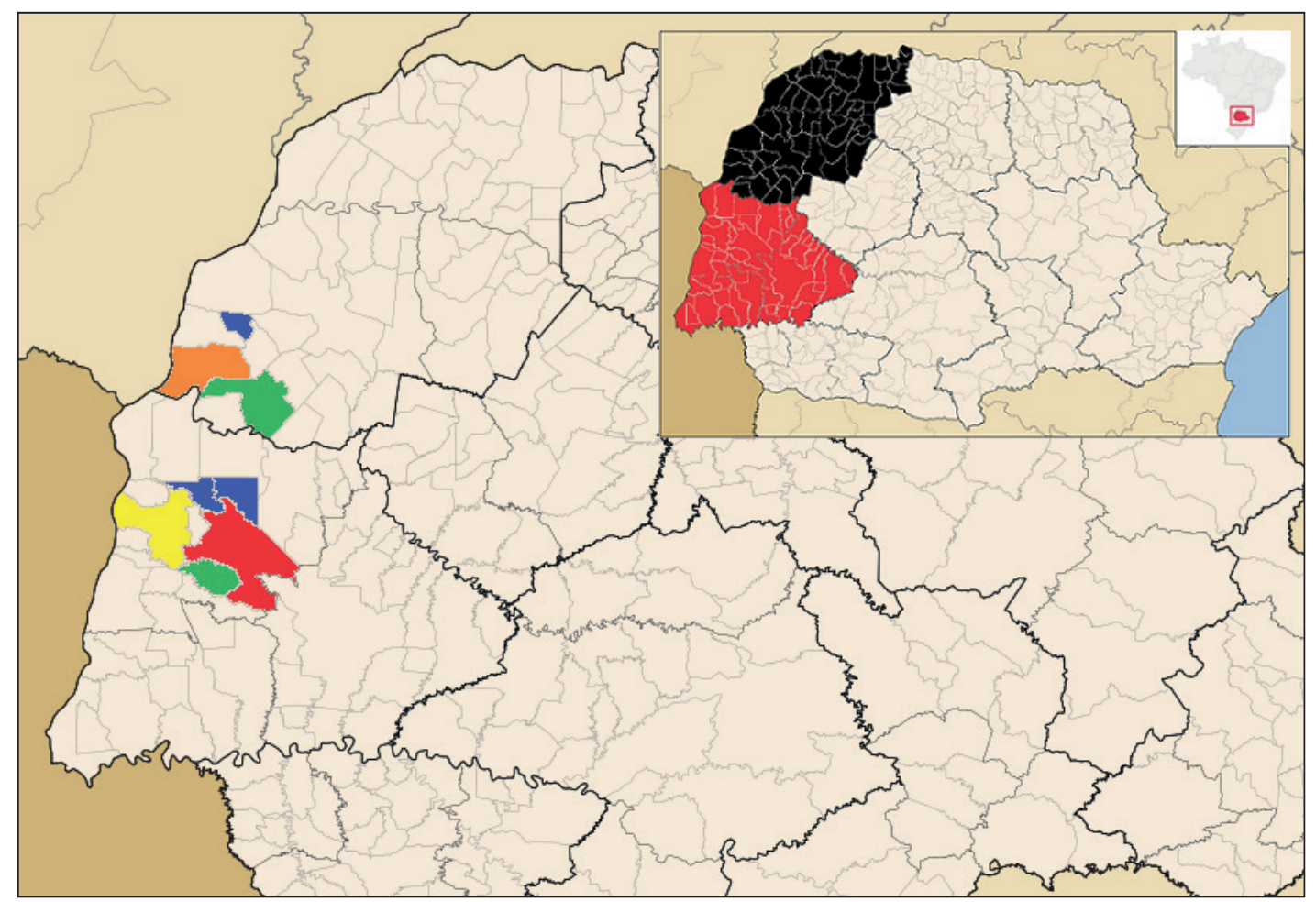


The findings of this study are in agreement with those of Carletti et al. (2005), who showed 2.6\% of positive animals among 395 animals evaluated from 13 slaughterhouses from various regions of Paraná. The authors also suggested decreased tendency of the prevalence of toxoplasmosis in this species due to the technological improvement of farms, with a lower prevalence among finishing animals, suggesting that the reduced length of stay of these animals on the farm has decreased the likelihood of infection by $T$. gondii. Moura et al. (2007) found a relative prevalence of $8.5 \%$ in slaughtered animals in Guarapuava region (PR). However, Millar et al. (2008) found $25.5 \%$ positive animals among 408 slaughtered animals from 25 municipalities in the southwestern region of Paraná. Therefore, the regional characteristics of pig farming can greatly contribute to the increase in infection rates.

In 1990, in the region of Londrina, Vidotto et al. (1990) used the indirect immunofluorescence technique and reported $37.84 \%$ seropositive animals from a total of 1,131 pigs from farms, with no difference with regard to age. Navarro et al. (1992) performed a bioassay technique in mice and reported that $23(19.6 \%)$ pig meat samples were positive for the presence of cysts of $T$. gondii from a total of 117 samples obtained from slaughterhouses in Londrina. Garcia et al. (1999) reported 24\% prevalence in Jaguapitã. Most of the studies were conducted at farms with low levels of management and technological improvement, i.e., subsistence farming, with rudimentary facilities and usually involving few animals, in direct contact with the land ; the diet varied from cereals (maize), remains of human food, and dead chickens. Further, 92.2\% of the titers were between 1:64 and 1:1,024, which may be suggestive of a latent infection in these animals.

In addition, in the northern region of Paraná, Tsutsui et al. (2003) observed $15.35 \%$ seropositivity in a total of 521 samples that were divided into three categories (boar, gilt, and sows). In this study, the analysis of the variables showed that an intensive farming system was a protective factor for the presence of $T$. gondii.

Piassa et al. (2010) found seropositive samples in $13.4 \%$ of animals slaughtered in the micro-region of Toledo. The authors suggested a list of risk factors and determined the following as protective factors: the use of different employees according to farm sector (which is directly related to technological improvement and mechanization of farms), and covering of water reservoirs meant for pigs. The likelihood of finding seropositive animals was 10 times higher in farms where the water reservoir was accessible to dogs, chickens, and rodents than in those that had covered water reservoirs. Lack of rodent control was associated with greater presence of infected animals. Kijlstra et al. (2008) showed reduced infected pigs raised on properties that had rodent control management, emphasizing its role in the maintenance of toxoplasmosis in the herd.

In Europe and North America, the technological improvement of production reduced the prevalence of $T$. gondii infection in young pigs (DUBEY, 2000; TENTER et al., 2000), although older animals (which are routinely used in the production of sausages, salami, and cured beef) had a higher prevalence (DUBEY, 2000). The risk of infection from the consumption of sausages produced using pig meat has been investigated in experimental studies. In Brazil and the United States, raw meat is usually derived from young animals, whereas sausages are often produced using meat from discarded animals that are usually older and, according to the literature, most often infected (DIAS et al., 2005; SILVA et al., 2010).

Taken together, our findings suggest a decrease in the prevalence of swine toxoplasmosis, probably due to sanitary improvements adopted in herds and greater technological improvement of properties. Although the consumption of pork in Brazil is lesser than that in other countries, meat needs to be adequately cooked in order to reduce the risk of infection in humans. 


\section{Conclusion}

Pigs raised and slaughtered in the northwestern region of the State of Paraná might be considered a source of $T$. gondii infection for humans.

For their cooperation in carrying out the IFI.

\section{Acknowledgements}

Universidade Paranaense - UNIPAR for the financial support to this research.

Universidade Estadual de Londrina - UEL for their cooperation in carrying out the IFI

\section{References}

BRASIL, Instituto Brasileiro de Geografia e Estatística. Pecuária, 2012. Disponível em: <http://cidades.ibge. gov.br/comparamun/compara.php?lang $=\&$ coduf $=41 \&$ idtema $=121 \& \operatorname{codv}=\mathrm{v} 06 \&$ search $=$ parana|toledo|pecuar ia-2012>. Acesso em: 26 fev. 2014.

CAMARGO, M. E. Introdução às técnicas de imunofluorescência. Revista Brasileira de Patologia Clinica, Rio de Janeiro, v. 10, n. 2, p. 143-171, 1973.

CARLETTI, R. T.; FREIRE, R. L.; SHIMADA, M. T.; RUFFOLO, B. B.; BEGALE, L. P.; LOPES, F. M. R.; NAVARRO, I. T. Prevalência da infecção por T. gondii em suínos abatidos no Estado do Paraná, Brasil. Semina: Ciências Agrárias, Londrina, v. 26, n. 4, p. 563-568, out./ dez. 2005.

DIAS, R. A. F.; NAVARRO, I. T.; RUFFOLO, B. B.; BUGNI, F. M.; CASTRO, M. V.; FREIRE, R. L. T. gondii in fresh pork sausage and seroprevalence in butchers from factories in Londrina, Paraná State, Brazil. Revista do Instituto de Medicina Tropical, São Paulo, v. 47, n. 4, p. 185-189, 2005.

DUBEY, J. P. Sources of T. gondii infection in pregnancy. British Medical Journal, Londres, v. 32, n. 512, p. 127 128, 2000.

. Toxoplasmosis in pigs - the last 20 years. Veterinary Parasitology, Amsterdam, v. 164, n. 2-4, p. 89-103, 2009.

DUBEY, J. P.; HILL, D. E.; JONES, J. L.; HIGHTOWER, A. W.; KIRKLAND, J. M.; ROBERTS, P. L.; MARCET, T.; LEHMANN, M. C. B.; VIANNA, K.; MISKA, C.; SREEKUMAR, O. C.; KWOK, C. H.; SHEN, S. K.; GAMBLE, H. R. Prevalence of viable T. gondii in beef, chicken, and pork from Retail meat stores in the united states: risk assessment to consumers. Journal Parasitology, v. 91, n. 5, p. 1082-1093, 2005.

FRENKEL, J. K. Toxoplasmosis in humans beings. Journal of the American Veterinary Medical Association, Schaumburg, v. 196, n. 2, p. 240-248, 1990.

Toxoplasma in and around us. BioScience, Reston, v. 23, n. 6, p. 343-352, 1973.

GARCIA, J. L.; NAVARRO, I. T.; OGAWA, L.; OLIVEIRA, R. C. Soroprevalência do T. gondii, em suínos, bovinos, ovinos e equinos e sua correlação com humanos, felinos e caninos, oriundos de propriedades rurais do norte do Paraná-Brasil. Ciência Rural, Santa Maria, v. 29, n. 1, p. 91-97, 1999.

HILL, D. E.; HALEY, C.; WAGNER, B.; GAMBLE, H. R.; DUBEY, J. P. Seroprevalence of and risk factors for $\mathrm{T}$. gondii in the US Swine hers using sera collected during the National Animal Health Monitoring Survey. Zoonoses and Public Health, Malden, v. 57, n. 87, p. 5359, 2010.

KIJLSTRA, A.; MEERBURG, B.; CORNELISSEN, J.; CRAEYE, S.; VEREIJKEN, P.; JONGERT, E. The role of rodents and shrews in the transmission of Toxoplasma gondii in pigs. Veterinary Parasitology, Amsterdam, v. 4, n. 156, p. 183-190, 2008.

KIM, K.; WEISS, L. M. Toxoplasma: the next 100 years. Microbes and Infection Journal, Elsevier, ed. 10, p. 978984, jul. 2008.

MILLAR, P. R.; DAGUER, H.; VICENTE, R. T.; COSTA, T.; SOBREIRO, L. G.; AMENDOEIRA, M. R. R. T. gondii: estudo soroepidemiológico de suínos da região sudoeste do Estado do Paraná. Pesquisa Veterinária Brasileira, Seropédica, ed. 28. n. 1, p. 15-18, jan. 2008.

MOURA, A. B.; OSAKI, S. C.; ZULPO, D. L.; MARANA, E. R. M. Ocorrência de anticorpos contra Toxoplasma gondii em suínos e ovinos abatidos no município de Guarapuava, PR, Brasil. Revista Brasileira de Parasitologia Veterinária, Jaboticabal, v. 16, n. 1, p. 54-56, 2007.

NAVARRO, I. T.; VIDOTTO, O.; GIRALDI, N.; FREIRE, R. L. T. gondii: isolamento a partir de carne e cérebro de suínos comercializados na região de Londrina, PR. Semina: Ciências Agrárias, Londrina, v. 13, n. 1, p. 32-34, mar. 1992.

PIASSA, F. R.; ARAUJO, J. B.; ROSA, R. C.; MATTEI, R. J.; SILVA, R. C.; LANGONI, H.; SILVA, A. V. Prevalence and risk factors for $T$. gondii infection in certified and non-certified pigs breeding farms in the 
Toledo microregion, PR, Brazil. Revista Brasileira de Parasitologia Veterinária, Jaboticabal, v. 19, n. 3, p. 152156, jul.-set. 2010

SILVA, A. V.; SILVA, R. C.; ZAMPROGNA, T. O.; LUCAS, T. M. T. gondii em suínos com ênfase na contribuição brasileira. Scientia Medica, Porto Alegre, v. 20, n. 1, p. 120-130, 2010.

TENTER, A. M.; HECKEROTH, A. R.; WEISS, L. M. T. gondii: from animals to humans. Journal for Parasitology, Oxford, v. 30, n. 2, p. 1217-1258, 2000.
TSUTSUI, V. S.; NAVARRO, I. T.; FREIRE, R. L.; FREITAS, J. C.; PRUDENCIO, L. B.; DELBEM, A. C. B.; MARANA, E. R. M. Soroepidemiologia e fatores associados à transmissão do $T$. gondii em suínos do norte do Paraná. Archives of Veterinary Science, Curitiba, v. 8, n. 2, p. 27-34, 2003.

VIDOTTO, O.; NAVARRO, I. T.; GIRALDI, N.; MITSUKA, R.; FREIRE, R. L. Estudos epidemiológicos da toxoplasmose em suínos da região de Londrina-Pr. Semina: Ciências Agrárias, Londrina, v. 11, n. 1, p. 5359, 1990. 